\title{
Hypopharyngeal Cancer Clinical Regional Lymph Nodes TNM Finding v8
}

National Cancer Institute

\section{Source}

National Cancer Institute. Hypopharyngeal Cancer Clinical Regional Lymph Nodes TNM

Finding v8. NCI Thesaurus. Code C132936.

A clinical finding about one or more characteristics of hypopharyngeal cancer, following the rules of the TNM AJCC V8 classification system as they pertain to stag ing of regional lymph nodes. 